\title{
The Quantitative Productivity of Full Time Working Male and Female Employees in Finland
}

\author{
Pauli Sumanen \\ Independent Working Time and Salary/Wage Researcher, Finland
}

Copyright $(\mathcal{C} 2015$ by authors, all rights reserved. Authors agree that this article remains permanently open access under the terms of the Creative Commons Attribution License 4.0 International License

\begin{abstract}
The objective of this research was to find a reliable method to measure the quantitative productivity of men and women to be used in the gender wage gap verification. For that purpose two different statistical survey materials were bought from the Statistics Finland: The Labour Force Survey material, which is based on phone calls, and weekly material of the Time Use Survey, which is based on handwritten diaries. The European Parliament resolution $2008 / 2012$ (INI) states in chapter G 'whereas the pay gap is not based solely on disparities in gross hourly earnings and account should also be taken of factors such as ... productivity, which should be measured not only in quantitative terms (hours when the worker is physically present in the workplace) ...' Results from the Time Use Survey indicate that approximately $13 \%$ of male employees and $4 \%$ of female employees work more than 50 hours per week. The annual working hours of full-time working male employees are $17-20 \%$ higher than working hours of female employees in a normal economic situation. The analysis of the Labour Force Survey material shows that the Time Use Survey is more reliable for measuring the quantitative productivity.
\end{abstract}

Keywords Annual Working Hours, The Labour Force Survey, Overtime Hours, Quantitative Productivity of Men and Women, The Time Use Survey

\section{Foreword: Why is it Important to Measure Quantitative Productivity (Productive Working Hours)?}

The legendary sociological equality research from the year 1968 of Elina Haavio-Mannila [1] states that one reason for the gender pay gap can be differences in the working hours of men and women. Her working hour notice is based on her own study of medical doctors.

The European Parliament resolution 2008/2012(INI) states in chapter $G$ 'whereas the pay gap is not based solely on disparities in gross hourly earnings and account should also be taken of factors such as individual pay supplements, job classification, work organisation patterns, professional experience and productivity, which should be measured not only in quantitative terms (hours when the worker is physically present in the workplace) but also in qualitative terms and in terms of the earnings impact of shorter working hours, leave and health-related absences'. [2]

ILO also refers to the need of using working hours in the pay gap verification. ILO UN Global Compact webinar [3] March 2011 asks: Equal Pay for Work of Equal Value. Why Gender Pay Gap? And answers:

Charasteristics of individuals and organisations:

- Educational level and field of study

- Work experience and seniority

- Number of working hours

- $\quad$ Size of organisation and sector activity

ILO states in its KILM-18 report [4], section 17 'Labour productivity' of working hours: 'Estimates of annual working hours are often unavailable or are relatively unreliable. Even for developed economies, annual working hours are not consistently defined. For example, statistics on working hours often refer to paid hours rather than to hours actually worked, implying that no adjustments are made for paid hours that are not worked, such as hours for paid vacation or sickness, or for hours worked that are not paid for'.

EU Commission states 'In the EU, the gender pay gap is referred to officially as the "unadjusted gender pay gap", as it does not take into account all of the factors that impact on the gender pay gap, such as differences in education, labour market experience, hours worked, type of job, etc.' [5]

Denmark has considered several indicators to describe the gender wage gap. In one of them, the annual working hours are noticed and it indicates that the gender wage gap is narrow. 'When the income per worked hour is measured, the gender pay gap is considerably lower than when the first three pay concepts are used.' [6]

\section{What Information is gathered from the Official Existing Statistics?}


There does not seem to be any study or statistics in Finland, which would indicat the number of yearly productive working hours by men and women, whose monthly pay is verified. Today in Finland 37\% of employees are controlled by stamp cards or electronic stamp systems, $34 \%$ of employees make reports manually and $29 \%$ of employees are followed only by their nearest boss without any reporting system [7]. Nevertheless, we can find some clues of the annual productive working hours of full-time working employees.

\subsection{The Time Use Survey}

Table 1 is calculated from the daily diaries of the Time Use Survey 3/1999 - 2/2000 in Finland. The surveyant gets two daily sheets, one for a predifined day between Monday-Friday and the second for Saturday or Sunday. The productive working hours of men were approximately 1908 hours and of women were approximately 1516 hours during 12 months between 3/1999 - 2/2000. The four left-hand sided columns are from the book. The last column 'All' is a weighted average from the three columns left. The weight is the number of employees in each socioeconomical group. The group 'Upper white collar' means in Finland employees who have studied four or more years after graduating from the high school. However, employees in the table 1 are not exactly the same as in the salary statistics. Here the part time employees are included. Also employees who were on a long sickness or parental leave up to one year are included [9]. Lunch time is separated from working time in this survey. In addition, we have to exclude hours from secondary jobs from the annual working hours [10]. When we eliminate the effect of all the aforementioned factors we get the result that full-time working men worked approximately 1940 hours per year and full-time working women approximately 1620 hours during the twelve consecutive months 3/1999-2/2000 in their main job. Men worked for approximately $20 \%$ hours more. The amount of hourly paid overtime hours is approximately 35 for men and 15 for women [11].

Table 1. Productive annual working hours of the employees from the Time Use Survey 3/1999-2/2000 of Statistics Finland, [8]. Employees divided into three socio economical groups.

\begin{tabular}{|c|c|c|c|c|}
\hline & $\begin{array}{c}\text { Upper white } \\
\text { collar }\end{array}$ & Lower white collar & Blue collar & All \\
\hline Men hours & 1965 & 1849 & 1904 & 1908.5 \\
\hline $\begin{array}{c}\text { Women } \\
\text { hours }\end{array}$ & 1442 & 1563 & 1479 & 1515.7 \\
\hline $\begin{array}{c}\text { Men } \\
\text { thousands }\end{array}$ & 261 & 211 & 478 & 950 \\
\hline $\begin{array}{c}\text { Women } \\
\text { thousands }\end{array}$ & 236 & 547 & 214 & 997 \\
\hline
\end{tabular}

\subsection{The Labour Force Survey}

This statistics does not include the same population of employees as in the salary statistics or those in the Time Use
Survey. Here, part-time employees and those temporarily laid-off employees who have still a valid working contract are included. Employees who were on a long sickness or parental leave for not more than three months are included. The working hours in the Labour Force Survey include lunch time if it is defined to be working time in the union or personal contract. Moreover, we have to exclude hourly salaried overtime hours and hours from secondary jobs from the annual working hours to get the same work, which is used in the salary statistics. Existing data of any collected statistics give us no possibility for all these corrections.

Table 2. Productive annual working hours from the Labour Force Survey of Statistics Finland. The last column is calculated from the first two columns.

\begin{tabular}{|c|c|c|c|}
\hline & $\begin{array}{c}\text { Total annual } \\
\text { working hours }\end{array}$ & Employees & $\begin{array}{c}\text { Annual hours per } \\
\text { employee }\end{array}$ \\
\hline Men & 1776810 & 989000 & 1797 \\
\hline Women & 1528138 & 986000 & 1550 \\
\hline
\end{tabular}

\subsection{Another Result from the Labour Force Survey}

From an official survey [10], Päivi Keinänen indicates a result that in 2008 full-time working male employees worked for 1800 and female for 1600 hours, according to the Labour Force Survey. Men worked for $12-13 \%$ hours more. In the article, there is no explanation regarding the calculation of figures and definition of terms. Unfortunately, 2008 was an abnormal year, Finland experienced recession like the other industrialised countries and the GNP of Finland rose only by $0.9 \%$ that year; thus, those figures are not verifiable to years before or after that. In the following year, 2009, GNP declined to $8.6 \%$. In the previous year, 2007, GNP rose to $4.5 \%$. The 'acceptable normal' situation needs to be $2.5 \%$ or more.

\subsection{Conclusion from the Official Statistics}

It is difficult to state exactly the number of hours that salaried full-time men work more than salaried women because the concept of full-time working employee and the populations are different in different statistics. We get a vision that full time working male employees work $12-20 \%$ more than female ones depending on the statistics used and the economic situation.

\section{Two New Studies from Productive Working Hours in Finland}

\subsection{Study 1: Working Hours of Male and Female Employees 3/1999-2/2000 from the Weekly Sheet of the Time Use Survey}

In this study, the weekly time sheet of the Time Use Survey is used. The Time Use Survey 1999-2000 had a 
weekly time sheet, which was filled by all employees who had a valid contract with their employer. The employee filled in the sheet what he/she did in 15-minute intervals during seven consecutive days. He/she also filled a time sheet for one week-end day and another day during the week. These sheets were filled in 10-minute intervals. From this double work, the reliability of the weekly time sheet can be verified. The results from both methods are rather equal. According to Pääkkönen [12], the weekly time sheet method indicates only a little lower working hour difference for men and women. Pääkkönen has also studied, who are those, who didn't answer the original survey. In his study he made a new survey from those who didn't answer and found that busy people are underrepresented among those who answered. So the total yearly working hours in the Time Use Survey are a little bit low, especially for men [13].

Table 3. Data from the weekly sheet of the Time Use Survey 3/1999$2 / 2000$

\begin{tabular}{|c|c|c|c|c|}
\hline & Men & Hours & Women & Hours \\
\hline $\begin{array}{c}\text { Weekly hours } \\
\text { 0.1-35 }\end{array}$ & 332,13 & 7857.33 & 493,50 & 11760.35 \\
\hline $\begin{array}{c}\text { Weekly hours } \\
\text { 36-40 }\end{array}$ & 323,86 & 12484.02 & 320,94 & 12192.71 \\
\hline $\begin{array}{c}\text { Weekly hours } \\
41-44\end{array}$ & 116,15 & 4924.41 & 93,80 & 3975.96 \\
\hline $\begin{array}{c}\text { Weekly hours } \\
\text { 45- }\end{array}$ & 260,13 & 14023.54 & 105,49 & 5431.74 \\
\hline Total & 1032,27 & 39289.30 & 1013,73 & 33360.76 \\
\hline
\end{tabular}

Table 3 includes the summary from the original weekly data from the Statistics Finland. To be more understandable the material is first summed and then reduced to describe the working hours of approximately 1000 employees. The original data was approximately 10000 employees. Note that those who received salary/wage, but who did not work because of holiday or long sickness or parental leave are missing. Furthermore, the table includes working time from hourly salaried/waged overtime hours and working hours from secondary jobs. In this study the employee him/herself defines if he/she is a part-time worker regardless the weekly working hours. Using this definition the number of part-time employees in 1999 was approximately $7 \%$ of men and approximately $17 \%$ of women, men working 19.5 hours/week and part-time women 20 hours per week. These figures are used to separate part-time working employees from full-time working ones in the next table 4.

In the table 4 the amount of part-time employees is calculated and they and their working hours are separated to the line 2. The number of salaried, absent employees (men $13 \%$, women $18 \%$ ) are added to those, who were working on the survey week. The sum can be seen on the line 'With absent employees'. In Finland, the Working Hours Act $(605 / 1996)$ states that employees must be paid an add-on for overtime hours. Add-ons are $50 \%$ and $100 \%$ per hour. Moreover, in Finland there are more than 200 union contracts where can be even better rules. Therefore, here is a rough estimate that hours between 40 and 44 per week are paid with $50 \%$ add-on and hours which exceed 44 have a
$100 \%$ add-on pay. Verified to reality this is an underestimate.

Result 1. Without overtime hours men work for approximately $9.5 \%$ more hours than women.

Result 2. With overtime hours men work for approximately $18 \%$ more hours than women.

Result 3. If we value overtime hours as described above (with $50 \%$ or $100 \%$ add-on) men work for approximately $23 \%$ more 'equally valued hours' than women.

Result 4 . Approximately $23 \%$ of men and $10 \%$ of women worked over 45 hours per week and approximately $13 \%$ of male employees and $4 \%$ of female employees work more than 50 hours per week. Cha and Weeden have studied that in the USA by 2000 approximately $19 \%$ of men and $7 \%$ of women worked over 50 hours per week. [14]

Result 5. The yearly working hours were for men 1790 and for women 1520. All full-time employees worked approximately 1660 hours per year.

Table 4. Part-time employees separated and with overtime add-on.

\begin{tabular}{|c|c|c|c|c|}
\hline & Men & Hours & Women & Hours \\
\hline Part time & 72,26 & 1409.05 & 172,33 & 3446.67 \\
\hline $\begin{array}{c}\text { Full time 0.1- } \\
35\end{array}$ & 259,87 & 6448.28 & 321,16 & 8313.68 \\
\hline $36-40$ & 323,86 & 12484.02 & 320,94 & 12192.71 \\
\hline $41-44$ & 116,15 & 4924.41 & 93,80 & 3975.96 \\
\hline Over 45 & 260,13 & 14023.54 & 105,49 & 5431.74 \\
\hline $\begin{array}{c}\text { Working (full } \\
\text { time) }\end{array}$ & 960,01 & 37880.25 & 841,39 & 29914.09 \\
\hline $\begin{array}{c}\text { With absent } \\
\text { employees }\end{array}$ & 1103,46 & & 1026,09 & \\
\hline $\begin{array}{c}\text { With overtime } \\
\text { add-on }\end{array}$ & & 40988.33 & & 30974.47 \\
\hline
\end{tabular}

Table 5. Summary of weekly working hours and percentages from the Time Use Survey 3/1999-2/2000, full-time employees

\begin{tabular}{|c|c|c|c|c|}
\hline & Men & $\%$ & Women & $\%$ \\
\hline $\begin{array}{c}\text { Short week (0.5-35 } \\
\text { hours/week) }\end{array}$ & 260 & 27.1 & 321 & 38.2 \\
\hline $\begin{array}{c}\text { Normal week (36-40 } \\
\text { hours/week) }\end{array}$ & 324 & 33.8 & 321 & 38.2 \\
\hline $\begin{array}{c}\text { Low overtime (41-44 } \\
\text { hours/week) }\end{array}$ & 116 & 12.1 & 94 & 11.2 \\
\hline $\begin{array}{c}\text { High overtime (45-49 } \\
\text { hours/week) }\end{array}$ & 112 & 11.7 & 61 & 7.3 \\
\hline $\begin{array}{c}\text { Extreme week (over 50 } \\
\text { hours/week) }\end{array}$ & 148 & 15.4 & 45 & 5.4 \\
\hline Total & 960 & 100 & 841 & 100 \\
\hline
\end{tabular}

Table 5 is calculated from those who had at least 0,5 working hours on the survey week. Note that approximately $13 \%$ of salaried men and $18 \%$ of women didn't work on the survey week.

Result 1: $73 \%$ and $62 \%$ of full-time working men and 
women worked respectively more than 36 hours per week.

Result 2: Only one week from three was 'normal' (36-40 hours) during the whole year.

Result3: Approximately $39 \%$ of men and $24 \%$ of women worked for more than 40 hours per week. Overtime begins from 36 to 40 hours per week depending on the working contract. Overtime figures from the Ministry of Employment and the Economy indicate that approximately $1.3 \%$ of working hours are paid on hourly basis as overtime. It makes approximately 0.5 hours per week, men work for approximately 0.7 hours, women work for approximately 0.3 hours per week.

Result 4: Those full-time working men who worked during the survey day at least 10 minutes worked for approximately $11 \%$ more hours than women. Those who did not work during the first survey day, but were paid that day or during the following six days are missing from the weekly sheet survey. The Labour Force Survey indicates that the percentage of salaried women being out of work for a whole week is approximately 18 and of men approximately 13 when calculated from the yearly material.

\subsection{Study 2. Weekly Working Hours from the Material IV/2007 of the Labour Force Survey}

The Labour Force Survey in Finland is conducted throughout the whole year. The material included here is based on the last quarter of 2007 that comprised 12 full weeks; the Independence Day week was 4 working days and the week with Christmas holiday was 2 working days. This constitutes a total of 14 weeks and 67 working days. Because the last quarter of the year is invalid to estimate the holiday weeks of the whole year, the zero-hour employees are not included in this study.

In the Labour Force Survey, the respondent is asked on the phone 'How many hours did you work during the last whole week (or during the whole week before the last)?'

In the original survey material, there are astonishingly many answers, which are above 80 hours per week. Some studies exclude them. However, the same amount of answers that exceed 80 hours is accepted as the ones equal to 80 hours in this study. Thus, answers by four males and three females are rejected. There is a doubt that they have included homework to their answers. In the Time Use Survey, see chapter 2.1, there were 18 men who had worked over 70 hours per week, but no women.

Those employees who did not work and did not get salary/wage are also included. They had a valid working contract, but they were on long sickness (majority were men) or parental leave (majority were women) or they were forbidden to come to work by the employer because of lack of work (majority were men). In the zero rows, there are also those who did not work but got salary/wage. They were on sickness or parental leave (majority women) or on holiday. Women have yearly more holiday than men. Most of the holiday is spent in the summer time, which is outside this survey material. The figures also include hours from hourly salaried/waged overtime hours and hours from secondary jobs. The working hours in the Labour Force Survey include lunch time if it is defined to be working time in the union or personal contract. Majority of those are women because this type of contract is used, for example, in the social, health, banking and insurance sectors.

Table 6. Summary of weekly working hours and percentages from the Labour Force Survey IV/2007, full-time employees

\begin{tabular}{|c|c|c|c|c|}
\hline & Men & $\%$ & Women & $\%$ \\
\hline $\begin{array}{l}\text { Short week (1-35 } \\
\text { hours/week) }\end{array}$ & 170,7 & 18.9 & 227,6 & 28.2 \\
\hline $\begin{array}{c}\text { Normal week (36-40 } \\
\text { hours/week) }\end{array}$ & 494,3 & 54.6 & 444,1 & 54.9 \\
\hline $\begin{array}{c}\text { Low overtime (41-44 } \\
\text { hours/week) }\end{array}$ & 48,8 & 5.4 & 48,8 & 6 \\
\hline $\begin{array}{l}\text { High overtime (45-49 } \\
\text { hours/week) }\end{array}$ & 83,5 & 9.2 & 49,2 & 6.1 \\
\hline $\begin{array}{c}\text { Extreme week (over } 50 \\
\text { hours/week) }\end{array}$ & 108 & 11.9 & 39 & 4.8 \\
\hline Total & 905,3 & 100 & 808,7 & 100 \\
\hline
\end{tabular}

In the table 6 only those are summed from the survey material of the Labour Force Survey who worked more than 0,5 hours per week. To be more understandable the material is divided proportionally into approximately 1000 employees. Those salaried employees who didn't work (13\% of men and $18 \%$ of women) are missing from the table 6. The original amount of employees in this survey was approximately 30000 . In the 'normal' week (36-40 hours) some employees are also included who work over 36 hours in a 4-day week, if they normally work more than 45 hours per week. Two weeks from 16 weeks were 4-day weeks on IV/2007. Hence, approximately half of the employees worked 'normally' in Table 8.

Result 1: $81.1 \%$ and $71.8 \%$ of full-time working men and women worked for more than 36 hours per week.

Result 2: Approximately only half of the weeks were 'normal' (36-40 hours).

Result 3: Full-time working men worked for approximately $12 \%$ more hours than women, when those who did not work during a survey week were rejected from the material.

There were approximately $5 \%$ more women than men who worked zero hours per week but got salary during 2007 . Employees who were absent the whole week but were paid include those on holidays, for example, have a long sickness or maternity/paternity leave, take their overtime as free or empty their time bank. The total non-productive working time in Finland is approximately $20 \%$ calculated from the normal annual working hours. The difference in working hours of full time working men and women during the fourth quarter of 2007 is approximately $17 \%$ according to the material from the Work Force Study. 


\section{Verification of the Two Surveys}

\section{Labour Force Study IV/2007}

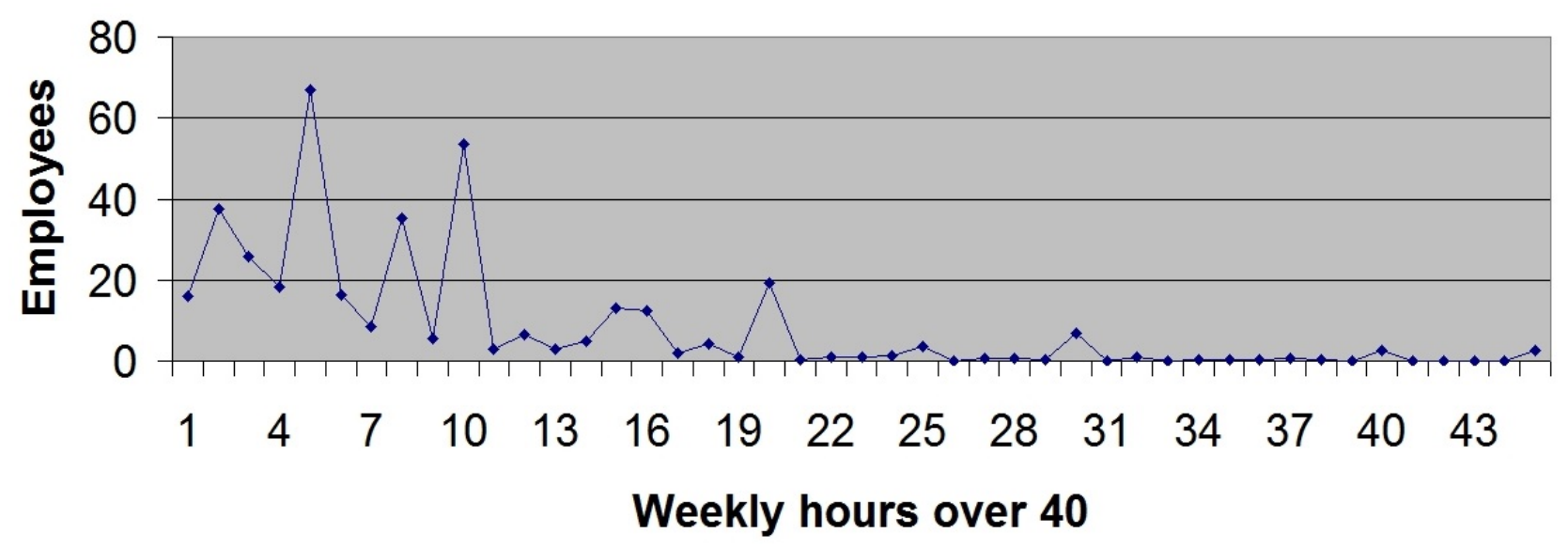

Figure 1. Hours that exceed 40 hours per week in the Labour Force Study

\subsection{Material}

The daily sheet in the Time Use Survey is at 10-minute intervals, the weekly sheet at 15-minute intervals. The accuracy in the Labour Force Survey is one hour.

If we take a better look at the Figure 1, the material in the Labour Force Survey is very uneven. From the detailed material, you can calculate that the values exceeding 44 hours concentrate on values $45,50,55,60 \ldots$ They represent $25 \%$ of possible values and they get 174 hits $(60 \%)$ from 292. The other time values $(46,47,48,49,51,52 \ldots)$ representing $75 \%$ of all values get only 118 hits (40\%). Extra high values tell that $6 \%$ of men and $3 \%$ of women had worked 85 hours per week. There must be some kind of misunderstanding what paid work is. In this study only two men and one woman are accepted to the calculations. No other corrections are made.

Both materials have the same problem. From the materials, you cannot see how many employees have not worked during the whole week, but were paid during absence.

\subsection{Differences in Results}

In the table 7 , the summary of working hours of employees from the Time Use Survey 3/1999-2/2000 and the Labour Force Survey 1999 is verified. The working hours change only slightly in a normal economic situation so the difference in time span can be allowed. Noting that the Labour Force Survey includes paid time from lunch for some professions we can say that the Labour Force Survey gives approximately $5 \%$ less difference between men and women in annual working hours. In the total sum of working hours of both sexes together (column 'All together hours'), the difference of $0,6 \%$ between two statistics is acceptable. In the Labour Force Survey, men seem to underestimate and women seem to overestimate their working hours verified to the Time Use Survey.

Table 7. Verification of results from the Time Use Survey and the Labour Force Survey

\begin{tabular}{|c|c|c|c|c|}
\hline & $\begin{array}{c}\text { All together } \\
\text { hrs }\end{array}$ & $\begin{array}{c}\text { Men million } \\
\text { hours }\end{array}$ & $\begin{array}{c}\text { Women M } \\
\text { hours }\end{array}$ & $\begin{array}{c}\text { Diff. } \\
\text { M/N }\end{array}$ \\
\hline $\begin{array}{c}\text { Time Use } \\
\text { Survey }\end{array}$ & $3324253 \mathrm{M}$ & 1813116 & 1511137 & $+20 \%$ \\
\hline $\begin{array}{c}\text { Labour } \\
\text { Force } \\
\text { Survey }\end{array}$ & $3304948 \mathrm{M}$ & 1776810 & 1528138 & $+16 \%$ \\
\hline
\end{tabular}

As mentioned above, there is a vast difference in these two materials. Male employees, who answer over the phone, do not perhaps remember that they have worked overtime and female employees perhaps forget that they have been absent from work. Employees answer in the Labour Force Survey that they work in normal week in $55 \%$ of all weeks, though the Time Use Survey indicates that they work in a normal week only in $35 \%$ of all weeks. Employees in these two surveys are not defined exactly similarly and we have to notice that from both surveys those, who did not work but were salaried/waged in their survey week are missing. Because women have more holidays and have more sickness and maternity leave, they are underrated in these surveys compared to the employees in the salary statistics where approximately $48.5 \%$ were females in 2000 . In Finland, we have up to three month full salaried maternal leaves and up to six month full salaried sickness leaves.

\subsection{Which is More Reliable, a Phone Call or the Diary Method?}

Professor Robinson[15] from the USA states '... the burden of evidence clearly points to the strong likelihood that time diaries are the only viable method of obtaining valid and reliable data on activities'. A Norwegian researcher Ragni Hege Kitterød [16] states in her study 
'There is no dispute that studies based on time diaries form the best data source concerning people's time allocation ...' A Danish Jens Bonke [17] states 'Time-use information is preferably obtained from diaries as this method is considered more reliable than information from questionnaires'. One reason, why other studies than time diaries are more unreliable according to Niemi [18], is that the the respondent answers how he/she feels to be inside the social acceptable standards. Laura Hulkko [19] describes the problems of the Labour Force Survey (phone calls): 1. In practice, the terms are not explained to the answerer during the phone call. 2 . The basic problem is the variety of the concept 'work'. Currently many employees are working outside their normal working place, by customer and home. In many professions, they are assumed to work outside their normal working time. 3 . The working time in the previous week or the week before the previous is always an estimate. Some employees tell their normal weekly working time despite the fact that they have worked overtime or have sometimes left earlier from work. 4 . Bigger abnormalities in one's working week are easier to remember but it is difficult to remember smaller ones. When we divide the difference in annual productive working hours of full-time working men and women in to three categories we get the following result: Men work more in all three categories. Approximately half of the difference (8-10 percentage units compared to all working hours) comprise hours which exceed 38.5 hours per week. Approximately one quarter (4-5 percentage units) comprise the difference in the normal working week when employees are working $1 / 2-38.5$ hours per week. Approximately one quarter (approximately 5 percentage units) comprise the whole week salaried absence from work.

\section{Conclusions}

In chapter 1, a study is presented, which tells that full-time working men contributed approximately $20 \%$ more annual working hours than women based on the data from the daily sheet of the Time Use survey 3/1999-2/2000. In chapter 2.1, a new study is presented, which tells that full-time working men contributed approximately $18 \%$ more annual working hours than women based on the data from the weekly sheet of the Time Use Survey 3/1999-2/2000. In chapter 2.2, there is yet another study which tells that full-time working men contributed approximately $17 \%$ more working hours than women based on the phone call data from the Labour Force Survey IV/2007. In last two results, the average absence of whole weeks of men and women is calculated from the whole year material of the Labour Force Survey. The difference in the annual productive working hours of full-time working men and women seems to be unchanged in a normal economic situation. It seems to be somewhere between $17 \%$ and $20 \%$. The results from the Time Use Survey from 2009 , when the GNP declined to $8.6 \%$, indicate that the regression lowers the working hours of men significantly more than the working hours of women [20]. To get the exact figure from an economically normal situation, one should make a Time Use Survey with weekly diary or a survey that is as reliable and connect the data on the employee level with the salary/wage data of the same month and verify that the employee gets salary/wage from the whole month. Because the working hours are dependent on the economic situation, the proper time to do this is in a 'normal' economic situation when the GNP increases approximately to $2.5-3 \%$ a year, which is seen to be a satisfactory growth in Finland.

\section{REFERENCES}

[1] Haavio-Mannila, Elina (1968), page 69, Suomalainen nainen ja mies (The Finnish woman and man), Asema ja muuttuvat roolit (Position and changing roles), WSOY Porvoo 1968

[2] EU Parliament Resolution 2008/2012(INI) (2008) Application of the principle of equal pay for men and women, http://www.europarl.europa.eu/sides/getDoc.do?pubRef=-//E $\mathrm{P} / / \mathrm{TEXT}+\mathrm{TA}+\mathrm{P} 6-\mathrm{TA}-2008-0544+0+\mathrm{DOC}+\mathrm{XML}+\mathrm{V} 0 / / \mathrm{EN}$

[3] ILO - UN Global Compact webinar march 2011, http://www.ilo.org/wcmsp5/groups/public/@ed_emp/@emp _ent/@multi/documents/meetingdocument/wcms_156288.pd $\overline{\mathrm{f}}$, read 18.1.2013

[4] ILO KILM-18 report section 17 'Labour productivity' http://kilm.ilo.org/2011/download/kilm17EN.pdf, read 22.4.2013

[5] European Commission-Directorate-General for Justice: Tackling the gender pay gap in the European Union, ISBN: 978-92-79-28821-0, 2013, page 5

[6] Foubert, Petra (2010), The Gender Pay Gap in Europe from a Legal Perspective, Luxembourg: Publications Office of the European Union, 2010, ISBN 978-92-79-16253-4, page 8

[7] 'Akavaaka 2010', Tietoa akavalaisista työelämässä, (Statistics from academic people in working life 2010), Kirjapaino (printing house) Uusimaa, 2010, ISBN 978-952-5618-29-6, page 28

[8] Tilastokeskus (Statistics Finland): Iiris Niemi, Hannu Pääkkönen: 'Ajankäytön muutokset 1990-luvulla', (Changes in time use between 1990-2000), Helsinki 2001. Kulttuuri ja viestintä 2001:6, ISBN 951-727-964-7, pages 21,67 and 69

[9] KELA:n tilastollinen vuosikirja 2000 (The statistical yearbook 2000 of the Social Security Institute of Finland), http://www.kela.fi/it/kelasto/kelasto.nsf/alias/Vk_00_pdf/\$Fi le/Vk_00.pdf?OpenElement, read 1.11.2012, pages 127-134

[10] Tilastokeskus (Statistics Finland), 'Työelämän suurten muutosten vuosikymmenet' (The Decades of Big Changes in Working Life), edited by Anna Pärnänen and Kaisa-Mari Okkonen, 2009, ISBN 978-952-244-132-4, Article: Päivi Keinänen: Palkansaajien työajan muutokset ja työaikamuodot, (Changes in working time and working time forms of employees), pages 113-118 
[11] Vartiainen, Juhana (2001) Sukupuolten palkkaeron tilastointi ja analyysi (The Statistics and Analysis of the Gender Pay Gap). Sosiaali- ja terveysministeriö (Ministry of Social and Health), Tasa-arvojulkaisuja (Equality publications) 2001:7, ISBN 951-47-6822-1, Edita Oyj, Helsinki, page 23

[12] Tilastokeskus (Statistics Finland) 'Työajan muutokset', (Changes in working time), editor Laura Hulkko, Helsinki 2003. ISBN 952-467-175-1, Työmarkkinat 2003:8, article Hannu Pääkkönen: Työajan mittaamisen menetelmäerot (Differences in the Methods of Measuring Working Time) pages $122-125$

[13] Dissertation of Hannu Pääkkönen, Perheiden aika ja ajankäyttö (The Time and Time Use of Families), 2010, ISBN 978-952-244-248-2 (pdf), article: Pääkkönen, Hannu (1998) Are busy people under- or overrepresented in national time budget surveys? Loisir et société /Society and Leisure 21 (2), http://tilastokeskus.fi/tup/julkaisut/tiedostot/isbn_978-952-2 44-248-2.pdf, read 15.9.2015, pages 573-582.

[14] Youngjoo Cha, Kim A. Weeden (2013) Overwork and the Slow Convergence in the Gender Gap in Wages, American Sociological Review, June 2014 vol. 79 no. 3 457-484

[15] John P Robinson (1985): The validity and reliability of diaries versus alternative time use measures (pages 33-62). Time, Goods and Well-being Edited by Juster and Stafford, Ann Arbor, University of Michigan 1985
[16] Kitterød, Ragni Hege (2001) Does the recording of parallel activities in Time Use Diaries affect the way people report their main activities?, Social Indicators Research, November 2001, Volume 56, Issue 2, pages 145-178, abstract: http://www.timeuse.org/node/1783, read 2.2.2014

[17] Bonke, Jens (2005) Paid Work and Unpaid Work: Diary Information Versus Questionnaire Information, Social Indicators Research, February 2005, Volume 70, Issue 3, pages 349-368, http://www.sfi.dk/graphics/SFI/Pdf/Working_papers/WP26J EBpaidandunpaidwork.pdf, read 2.2.2014

[18] Niemi, Iiris: Systematic Error in Behavioural Measurement: Comparing Results from Interview and Time Budget Studies. Magazine: Social Indicators Research, number 30, November 1993, Editor Alex C. Michalos, 1993 Kluwer Academic Publishers. Printed in the Netherlands, pages 229-244

[19] Hulkko, Laura (2004) Selvitys työaikojen tilastoinnista Suomessa ja kansainvälisesti (A description of the statistics of the working times in Finland and Internationally), Tilastokeskus: Työajat Suomen työvoimatutkimuksessa, ISBN 952-467-327-4, Edita Prima, http://tilastokeskus.fi/tup/julkaisut/tiedostot/isbn_952_467_3 27_4.pdf, read 2.2.2014, pages 17-19

[20] Ajankäyttötutkimus 2009 (Time Use Survey 2009), Statistics Finland, 2011, ISSN 1799-5639 (pdf) read 15.9.2015, page 4 